\title{
Front Matter: Volume 10050
}

, "Front Matter: Volume 10050," Proc. SPIE 10050, Clinical and Translational Neurophotonics, 1005001 (13 April 2017); doi: 10.1117/12.2270041

SPIE. Event: SPIE BiOS, 2017, San Francisco, California, United States 


\title{
Clinical and Translational Neurophotonics
}

\author{
Steen J. Madsen \\ Victor X. D. Yang \\ Editors
}

28-29 January 2017

San Francisco, California, United States

Sponsored and Published by

SPIE 
The papers included in this volume were part of the technical conference cited on the cover and title page. Papers were selected and subject to review by the editors and conference program committee. Some conference presentations may not be available for publication. The papers published in these proceedings reflect the work and thoughts of the authors and are published herein as submitted. The publisher is not responsible for the validity of the information or for any outcomes resulting from reliance thereon.

Please use the following format to cite material from these proceedings:

Author(s), "Title of Paper," in Clinical and Translational Neurophotonics, edited by Steen J. Madsen, Victor X. D. Yang, Proceedings of SPIE Vol. 10050 (SPIE, Bellingham, WA, 2017) Seven-digit Article CID Number.

ISSN: 1605-7422

ISSN: 2410-9045 (electronic)

ISBN: 9781510605411

ISBN: 9781510605428 (electronic)

Published by

SPIE

P.O. Box 10, Bellingham, Washington 98227-0010 USA

Telephone +1 3606763290 (Pacific Time) · Fax +1 3606471445

SPIE.org

Copyright (C) 2017, Society of Photo-Optical Instrumentation Engineers.

Copying of material in this book for internal or personal use, or for the internal or personal use of specific clients, beyond the fair use provisions granted by the U.S. Copyright Law is authorized by SPIE subject to payment of copying fees. The Transactional Reporting Service base fee for this volume is $\$ 18.00$ per article (or portion thereof), which should be paid directly to the Copyright Clearance Center (CCC), 222 Rosewood Drive, Danvers, MA 01923. Payment may also be made electronically through CCC Online at copyright.com. Other copying for republication, resale, advertising or promotion, or any form of systematic or multiple reproduction of any material in this book is prohibited except with permission in writing from the publisher. The CCC fee code is 1605 $7422 / 17 / \$ 18.00$.

Printed in the United States of America.

Publication of record for individual papers is online in the SPIE Digital Library.

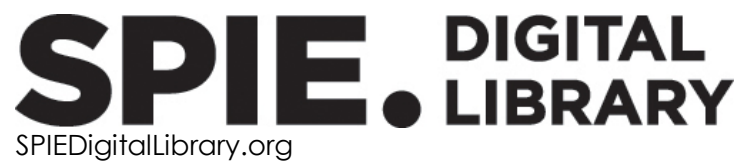

Paper Numbering: Proceedings of SPIE follow an e-First publication model, with papers published first online and then in print. Papers are published as they are submitted and meet publication criteria. A unique citation identifier (CID) number is assigned to each article at the time of the first publication. Utilization of CIDs allows articles to be fully citable as soon as they are published online, and connects the same identifier to all online, print, and electronic versions of the publication. SPIE uses a seven-digit CID article numbering system in which:

- The first five digits correspond to the SPIE volume number.

- The last two digits indicate publication order within the volume using a Base 36 numbering

system employing both numerals and letters. These two-number sets start with 00, 01, 02, 03, 04, $05,06,07,08,09,0 A, 0 B \ldots$. OZ, followed by 10-1Z, 20-2Z, etc.

The CID Number appears on each page of the manuscript. The complete citation is used on the first page, and an abbreviated version on subsequent pages. 


\title{
Contents
}

\author{
$\checkmark$ Authors \\ vii Conference Committee
}

OPERATIVE AND POST OP. THERAPY I

1005002 Multi-scale spectrally resolved quantitative fluorescence imaging system: towards neurosurgical guidance in glioma resection [10050-1]

1005005 Fiber-probe optical spectroscopy discriminates normal brain from focal cortical dysplasia in pediatric subjects [10050-4]

\section{OPERATIVE AND POST OP. THERAPY II}

10050 OG A comparison between antidepressant effects of transcranial near-infrared laser and citalopram in a rat model of depression [10050-14]

\section{NEURONAVIGATION}

10050 ol Spinal intra-operative three-dimensional navigation with infra-red tool tracking: correlation between clinical and absolute engineering accuracy [10050-16]

$10050 \mathrm{OJ}$ 3D point cloud analysis of structured light registration in computer-assisted navigation in spinal surgeries [10050-17]

\section{OPTICAL SPECTROSCOPY AND TOMOGRAPHY II}

1005000 In vivo imaging of tissue scattering parameter and cerebral hemodynamics in rat brain with a digital red-green-blue camera [10050-22]

$10050 \mathrm{OQ}$ Evaluation of spontaneous low-frequency oscillations in cerebral hemodynamics with time-series red-green-blue images [10050-24]

\section{OPTICAL SPECTROSCOPY AND TOMOGRAPHY III}

$10050 \mathrm{OV}$ Intraoperative optical coherence tomography of the cerebral cortex using a 7 degree-of freedom robotic arm [10050-29] 
POSTER SESSION

$10050 \mathrm{OZ}$ Multimodal optical coherence tomography for in vivo imaging of brain tissue structure and microvascular network at glioblastoma [10050-33] 


\section{Authors}

Numbers in the index correspond to the last two digits of the seven-digit citation identifier (CID) article numbering system used in Proceedings of SPIE. The first five digits reflect the volume number. Base 36 numbering is employed for the last two digits and indicates the order of articles within the volume. Numbers start with 00, 01, 02, 03, 04, 05, 06, 07, 08, 09, 0A, 0B...0Z, followed by 10-1Z, 20-2Z, etc.

Anand, Suresh, 05

Buccoliero, Anna Maria, 05

Cicchi, Riccardo, 05

Conti, Valerio, 05

Desjardins, Adrien, 02

Elagin, Vadim $\mathrm{V} ., \mathrm{OZ}$

Giordano, Flavio, 05

Gladkova, Natalia D., OZ

Gubarkova, Ekaterina V., OZ

Guerrini, Renzo, 05

Guha, Daipayan, 0l, 0J

Gupta, Shaurya, Ol, OJ

Jakubovic, Raphael, Ol, OJ

Jivraj, Jamil, OV

Karabut, Maria M., $\mathrm{OZ}$

Kawauchi, Satoko, 0O, $0 Q$

Kiseleva, Elena B., $\mathrm{OZ}$

Kokubo, Yasuaki, 0O, OQ

Kravets, L. Ya., $\mathrm{OZ}$

Matveev, Lev A., $0 Z$

McEvoy, Andrew W., 02

Medyanik, Igor A., $0 Z$

Miserocchi, Anna, 02

Mohaddes, Gisou, OG

Mustari, Afrina, $0 \mathrm{O}, \mathrm{OQ}$

Nakamura, Naoki, $0 Q$

Nishidate, Izumi, $00,0 Q$

Ourselin, Sebastien, 02

Pavone, Francesco Saverio, 05

Rasta, Seyed Hossein, OG

Reyes Perez, Robnier, OV

Sadigh-Eteghad, Saeed, OG

Salarirad, Sima, OG

Salehpour, Farzad, OG

Sato, Manabu, $00,0 Q$

Sato, Shunichi, $00,0 Q$

Sirotkina, Marina A., $\mathrm{OZ}$

Thom, Maria, 02

Vercauteren, Tom, 02

Xie, Yijing, 02

Yang, Victor X. D., Ol, OJ, OV

Yashin, Konstantin S., $0 Z$ 
Proc. of SPIE Vol. $100501005001-6$

Downloaded From: https://www.spiedigitallibrary.org/conference-proceedings-of-spie on 26 Apr 2023 Terms of Use: https://www.spiedigitallibrary.org/terms-of-use 


\title{
Conference Committee
}

\author{
Symposium Chairs \\ James G. Fujimoto, Massachusetts Institute of Technology \\ (United States) \\ R. Rox Anderson, Wellman Center for Photomedicine, Massachusetts \\ General Hospital (United States) and Harvard School of Medicine \\ (United States)
}

Program Track Chairs:

Rafael Yuste, Columbia University (United States)

David Boas, Massachusetts General Hospital, Harvard Medical School (United States)

Conference Chairs

Steen J. Madsen, University of Nevada, Las Vegas (United States)

Victor X. D. Yang, Ryerson University (Canada)

Conference Program Committee

David Abookasis, Ariel University of Samaria (Israel)

Frederic Leblond, Ecole Polytechnique de Montréal (Canada)

Herbert Stepp, Ludwig-Maximilians-Universität München (Germany)

Pablo A. Valdes, Dartmouth College (United States)

Session Chairs

1 Operative and Post Op. Therapy I

Victor X. D. Yang, Ryerson University (Canada)

2 Optical Spectroscopy and Tomography I

Steen J. Madsen, University of Nevada, Las Vegas (United States)

3 Operative and Post Op. Therapy II

Frédéric Leblond, Ecole Polytechnique de Montréal (Canada)

4 Neuronavigation

Steen J. Madsen, University of Nevada, Las Vegas (United States)

5 Optical Spectroscopy and Tomography II

David Abookasis, Ariel University of Samaria (Israel) 
6 Optical Spectroscopy and Tomography III

David Abookasis, Ariel University of Samaria (Israel)

viii

Proc. of SPIE Vol. $100501005001-8$

Downloaded From: https://www.spiedigitallibrary.org/conference-proceedings-of-spie on 26 Apr 2023 Terms of Use: https://www.spiedigitallibrary.org/terms-of-use 